\title{
Social structure and technology spillovers from foreign to domestic firms
}

\author{
Alex Eapen \\ Discipline of International Business, The \\ University of Sydney Business School, Sydney, \\ Australia \\ Correspondence: A Eapen, Discipline of \\ International Business, The University of \\ Sydney Business School, NSW 2006, \\ Australia. \\ Tel: +612903 66435; \\ Fax: +612903 65378; \\ Email: alex.eapen@sydney.edu.au
}

\begin{abstract}
Do domestic firms benefit from the presence of foreign multinational firms? The FDI spillovers literature addresses this very issue, primarily examining whether the presence of foreign firms in a host market leads to technology spillovers and upgrading in domestic firms. A key finding is that spillovers depend on the absorptive capacity of the domestic firm. Yet, in conceptualizing absorptive capacity, scholars have largely overlooked how social structure shapes it. Integrating insights from social networks, technology upgrading, and innovation literatures, I emphasize that a domestic firm's ability to absorb spillovers depends on the social structure it is embedded in. I argue that ties with foreign firms reduce the constraints that domestic firms usually face in searching for and transferring in foreign technologies. However, while search benefits from sparse network structures, transfer is facilitated by cohesive ones. Also, while affect-based ties might motivate foreign firms sufficiently to share information with domestic firms at the search stage, reciprocal benefits and social monitoring conferred by common third-party ties are necessary in the transfer stage. Any effect of ties also depends on the routine repertoire of domestic firms. Put together, these arguments offer a more socialized account of the spillover process.
\end{abstract}

Journal of International Business Studies (2012) 43, 244-263. doi: I0.1057/jibs.20 I 2.2

Keywords: knowledge and productivity spillovers; networks; absorptive capacity

\section{INTRODUCTION}

Do domestic firms benefit from the presence of foreign multinational firms? The literature on FDI spillovers ${ }^{1}$ addresses this very issue, primarily examining whether the presence of foreign multinational enterprises (MNEs) in a host market leads to technology spillovers to domestic firms (see Eden, 2009, for an excellent background, and Görg \& Strobl, 2001; Meyer, 2004; Meyer \& Sinani, 2009, for reviews). In recent years, scholars have made significant theoretical progress in clarifying how and when spillovers occur. Among other things, we now know that the characteristics of domestic firms, and in particular their absorptive capacity, are important determinants of whether they adopt foreign technologies and thus experience FDI spillovers (Blalock \& Simon, 2009; Girma, 2005; Liu, Siler, Wang, \& Wei, 2000; Liu, Wang, \& Wei, 2009; Meyer \& Sinani, 2009; Spencer, 2008).

The process of adopting any new technology involves a search and transfer phase. Potential adopters search and evaluate available 
alternatives, and subsequently negotiate the transfer, integration, and implementation of a chosen technology (Hansen, 1999; Hansen, Mors, \& Lovas, 2005). Search and transfer are inherently difficult processes, because search requires access to a diverse range of knowledge sources (Mors, 2010; Tortoriello \& Krackhardt, 2010), and transfer requires repeated, intensive interaction between the source and the recipient (Kotabe, Martin, \& Domoto, 2003; McDermott \& Corredoira, 2010). In the context of FDI spillovers, which are informal transfers (Eden, 2009), these difficulties are compounded. Information exchange and interaction between domestic and foreign firms must occur despite not being formally contracted for, and in spite of competitive considerations between them. The absorptive capacity of domestic firms that matters for FDI spillovers thus entails their ability to cut through search and transfer constraints. In other words, absorptive capacity encompasses the ability both to search for foreign technologies, and to transfer and implement the chosen technology (Cohen \& Levinthal, 1990; Phene \& Almeida, 2008; Todorova \& Durisin, 2007).

The treatment of absorptive capacity in the FDI spillovers literature, however, has been relatively narrow. First, scholars have focused predominantly on the transfer phase. Meyer and Sinani (2009: 1078), for example, say that "absorptive capacity captures firms' ability to utilize acquired knowledge and thus to increase their realized spillovers." Yet the ability of domestic firms to search the foreign technology space in the first instance is an equally crucial component (Todorova \& Durisin, 2007). Second, absorptive capacity has been considered largely a function of domestic firms' internal technical capabilities, eschewing the role of external inter-firm network ties (McDermott \& Corredoira, 2010: 327). Yet literatures on social networks, innovation, and technology upgrading show that social network ties serve as platforms for interactions between source and recipient firms that are crucial to search and transfer (Hansen, 1999; Larson, 1992; McDermott \& Corredoira, 2010; Saxenian, 1994; Uzzi, 1997). Thus, to fully conceptualize how absorptive capacity matters to FDI spillovers, besides broadening the remit of the construct to encompass both search and transfer abilities, it needs to be "framed in a way that accounts for both existing knowledge and the (network) relations that facilitate information exchange" (Borgatti \& Cross, 2003: 442).

This is what I do in this paper. My baseline argument is that domestic firms with network ties to foreign firms, compared with those without such ties, are better positioned to overcome search and transfer constraints. The effectiveness of network ties in facilitating search, however, depends on the network structure surrounding the tie (Burt, 1992), and on the affective quality of the tie (Adler \& Kwon, 2002; Gulati, 2007; Kilduff \& Brass, 2010). Bridging ties embedded in sparse network structures facilitate domestic firms' search for appropriate foreign technologies, and more so when the foreign partner is better motivated to overlook competitive considerations and share useful information, such as in the case of affective or friendship-based ties (Ingram \& Roberts, 2000; Krackhardt, 1992; Tsai, 2002). The transfer stage, on the other hand, requires much tighter coupling and interaction between foreign and domestic firms, and stronger incentives for foreign firms to commit the time and effort to knowledge-sharing (Hansen, 1999; Kotabe et al., 2003; Sako, 1996). Sparse ties and friendship considerations that support the search process may not incentivize foreign firms sufficiently to cooperate in the transfer stage; rather, cohesive network structures and the potential for future knowledge benefits from the domestic firm will (Coleman, 1988; Ingram \& Roberts, 2000; Reagans \& McEvily, 2003; Tortoriello \& Krackhardt, 2010). Any effect of ties, however, is contingent on the existing routines of the domestic firm. Domestic firms' repertoire of routines and capabilities that are complementary to the new technology somewhat substitutes the utility of ties. On the other hand, domestic firms with high change constraints, due partly to inertial pressures of existing routines, benefit more from ties.

Collectively, these arguments extend the theory of FDI spillovers in several important ways. First, I reframe the role of absorptive capacity of domestic firms on spillovers by focusing on those firms' ability to search as well as transfer. This extends existing conceptualization in the FDI spillovers literature, which focuses mostly on the ability of domestic firms to integrate and implement foreign technologies. Second, I elaborate on the role of network ties in the search and transfer stages of FDI spillovers. While the argument that spillovers depend on the embeddedness of the foreign firm has been proposed previously (e.g., Spencer, 2008), I extend this in significant ways to cover the types of ties and network structures that matter in different stages, the mechanisms that underlie the usefulness of ties, and the contingencies under 
which the effect of ties is stronger in abating search and transfer constraints. In doing so, I bring unprecedented attention to the role of social structure in FDI spillovers. Third, I bring to the surface some of the social mechanisms underpinning FDI spillovers, and thus portray a more socialized account of the FDI spillovers process. The theoretical model I develop sits at the intersection of the FDI spillovers and social networks literatures, and reconciles FDI spillover theory with the sociological argument that actors are influenced by their social connections with others. This is in contrast to the extant literature, which has been characterized largely by economic arguments (Eden, 2009; Meyer, 2004) and an under-socialized view of spillovers. Finally, by highlighting separately the stages of search and transfer, I offer a process view of FDI spillovers. This again is a novel perspective in the literature, which has given short shrift to the process of technology adoption by domestic firms. This is possibly also a legacy of the economics approach in the literature; as Nelson and Winter (1982: 126) rather bluntly remark, "economists ordinarily profess a complete lack of interest in the process by which firms actually make decisions" (italics added).

In the next sections, by way of providing a background for the discussion, I explain what FDI spillovers are, and review the literature to highlight the research gap that motivates this paper. Subsequently, I present the arguments that systematically build up my theoretical framework, and suggest several propositions. In the final section, I discuss scholarly and practical implications, empirical strategies, and possible future extensions.

\section{BACKGROUND: WHAT ARE SPILLOVERS?}

While the broader question of interest is the overall welfare effect of foreign MNEs on host economies (e.g., MacDougall, 1960; Meyer, 2004), the FDI spillover literature focuses specifically on technology benefits (Eden, 2009). Accordingly, empirical studies look for "observed improvements in productivity among firms that come in contact with FDI" (Meyer, 2004: 262). There are exceptions, however. For example, while Chang and Xu (2008) examine the effect of foreign MNEs on domestic firm survival, Ayyagari and Kosova (2010), Gu and Lu (2011), and Liu et al. (2010) study their effect on domestic entrepreneurship, domestic firm internationalization, and local innovation, respectively. For the sake of consistency with the majority,
I define FDI spillovers in this paper as informal transfers of technological know-how from foreign to domestic firms.

There are several notions that underpin the concept of FDI spillovers. The first is the idea that foreign MNEs carry superior technologies. The theoretical rationale for this comes from previous research on the theory of the MNE (Hennart, 1982; Hymer, 1976), which argues that multinational firms exist because of a proprietary firm-specific advantage. In many cases this advantage is a superior technology; the MNE subsidiary thereby serves as a carrier of superior technology (Findlay, 1978).

A second important notion is that formalized knowledge transfers from the foreign to the domestic firm, such as in the framework of a technology license agreement, fall outside the definitional remit of spillovers. Instead, spillovers are informal exchanges where the transferor is not directly remunerated for the knowledge (Eden, 2009). Some hold that spillovers, besides being informal, are also involuntary, occurring without the voluntary cooperation of foreign firms. This notion implies, however, that domestic firms can effortlessly imitate foreign firms (and their technologies) without any assistance from the latter. This is a fairly strong assumption, given what we know about the difficulties of transferring and replicating knowledge effectively within and across firms (Bechky, 2003; Nelson \& Winter, 1982; Teece, 1986). In fact, studies show that even in spite of formal mechanisms, knowledge transfer is extremely difficult (Dyer \& Hatch, 2006; McDermott \& Corredoira, 2010; Tsai, 2002). Some amount of cooperation from foreign firms is crucial to effective spillovers. In our view thus, and as I depict in

\begin{tabular}{|c|c|c|}
\hline & Transfer is voluntary & Transfer is involuntary \\
\hline $\begin{array}{c}\text { Knowledge transfer } \\
\text { is formal, and } \\
\text { foreign firm is } \\
\text { remunerated }\end{array}$ & $\begin{array}{l}\text { Not spillovers } \\
\text { e.g., knowledge } \\
\text { transfer within, say, } \\
\text { a licensing contract }\end{array}$ & Undefined \\
\hline $\begin{array}{c}\text { Knowledge transfer } \\
\text { is informal }\end{array}$ & $\begin{array}{c}\text { Spillovers } \\
\text { Knowledge } \\
\text { spillovers that } \\
\text { are informal but } \\
\text { voluntary }\end{array}$ & $\begin{array}{c}\text { Spillovers } \\
\text { e.g., knowledge that is } \\
\text { not contracted for, but } \\
\text { nevertheless spills over } \\
\text { while foreign and domestic } \\
\text { firms are engaged in a } \\
\text { formal licensing contract }\end{array}$ \\
\hline
\end{tabular}

Figure 1 Involuntary and voluntary knowledge transfers as constituting spillovers. 
Figure 1, voluntary transfers, too, fall under the rubric of spillovers, as long as they are informal and not formally contracted for. By several accounts, informal but voluntary sharing of knowledge, even among competitors, is quite common (Peteraf \& Shanley, 1997; Porter, 1990; Schrader, 1991; von Hippel, 1987). ${ }^{2}$

Finally, in terms of the content of spillovers, as the literature on technology upgrading shows (Giuliani, Pietrobelli, \& Rabellotti, 2005; McDermott \& Corredoira, 2010; McDermott, Corredoira, \& Kruse, 2009), technology upgrading of domestic firms can be process or product related. Processrelated know-how is that which makes firms better at "transforming inputs into outputs more efficiently by reorganizing the production system or introducing superior technology" (Giuliani et al., 2005: 552). Product upgrading, on the other hand, relates to moving into "more sophisticated product lines in terms of increased unit values" (McDermott \& Corredoira, 2010: 311).

\section{LITERATURE REVIEW}

An early treatment of FDI spillovers is the work of MacDougall (1960), which focuses on the benefits and costs of foreign private investment for hostcountry welfare, and specifically on real income. Among the various effects outlined in his model, MacDougall allows for possible "external economies" arising from foreign investment. Whereas MacDougall's analysis is for the most part static, Findlay (1978) presents a dynamic model, where the rate of change of technical efficiency in technologically backward regions is endogenous to the degree to which it is exposed to foreign capital. As a precursor to many subsequent models in the literature, Findlay models the rate of technological progress of the host country as a function of the relative technical efficiency of both the host and home countries - what subsequent literature refers to as the "technology gap" - and the extent of foreign presence in the host country. The technology gap allows greater room for efficiency improvements, and the exposure to foreign firms provides the contact necessary for efficiency improvements to occur. The key mechanism here is "contact with firms of a higher level of efficiency [which] enables the relatively backward ones to improve not only by copying or imitating but also by inducing them to try harder" (Findlay, 1978: 5). While these two early studies highlight contact and labor mobility, another channel through which foreign firms can have an effect is their vertical linkages with domestic firms (Hirschman, 1958; Lall, 1980; Markusen \& Venebles, 1999; Rodriguez-Clare, 1996). ${ }^{3}$

An important advance in theoretical development in recent years is the idea that spillover effects are not uniformly distributed but vary with domestic firm characteristics. In this vein, scholars have examined the effects on spillovers of domestic firms' export orientation, ownership structure and size (Sinani \& Meyer, 2004). Another argument, one I briefly alluded to earlier, is the technology gap hypothesis that spillovers are more likely when there is a technology gap between domestic and foreign firms. In such circumstances there is a bigger backlog and a greater opportunity for technology upgrades in domestic firms (Findlay, 1978; Meyer \& Sinani, 2009). Partly related to this, a notion that has gained significant traction in recent times is that spillovers accrue mainly to domestic firms with appropriate absorptive capacity (Blalock \& Simon, 2009; Girma, 2005; Liu et al., 2000; Zhang, Li, Li, \& Zhou, 2010). Absorptive capacity is the ability of a firm to "recognize the value of new, external information, assimilate it, and apply it to commercial ends" (Cohen \& Levinthal, 1990: 128). Firms with extremely low or high absorptive capacity may not benefit from spillovers (Girma, 2005), because the former do not have the minimum threshold level of knowledge to absorb foreign technology, and the latter presumably already operate near the technology frontier, and thus have little to learn from foreign firms (Haskel, Pereira, \& Slaughter, 2002). Firms with moderate levels of absorptive capacity, on the other hand, are better able to "connect new knowledge with existing knowledge and ... transform it for application in their own context" (Meyer \& Sinani, 2009: 1078). Portrayed largely as a function of prior related technical knowledge, absorptive capacity is often measured in the empirical spillovers literature using domestic firms' R\&D and human capital investments (e.g., Blalock \& Simon, 2009).

\section{THEORY DEVELOPMENT}

\section{Literature Gap and Motivation}

While significant progress has undoubtedly been made in understanding when spillovers might occur, two issues require further attention. First, there has not been much discussion around the search stage in the process of adopting foreign technologies. While firms' ability to search and evaluate new technologies is an important component of their absorptive capacity (Cohen \& 


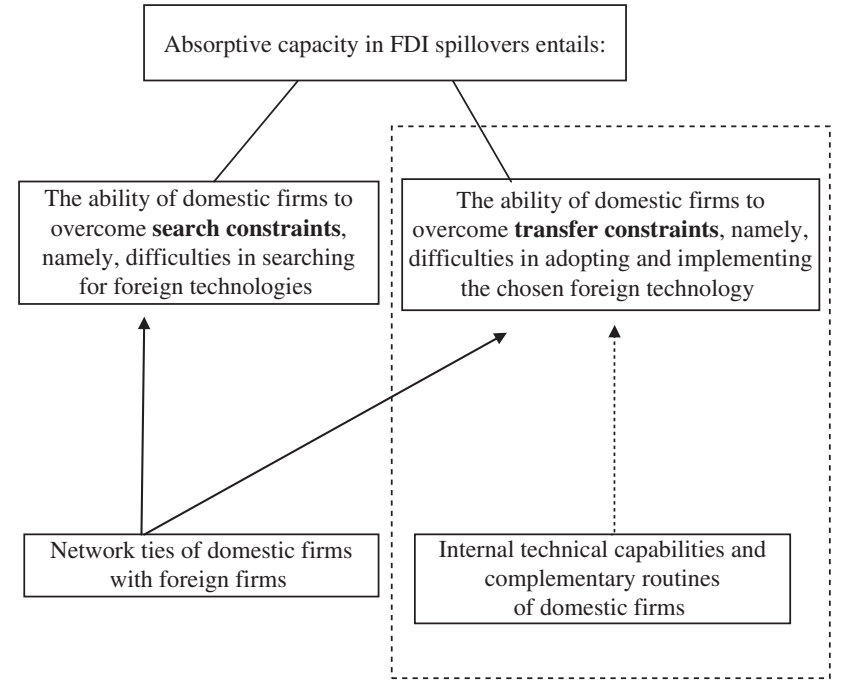

Figure 2 Components of domestic firms' absorptive capacity, and its determinants.

Note: The extant FDI spillovers literature has mostly conceptualized absorptive capacity as the ability of domestic firms to overcome transfer constraints (denoted by the area inside the dotted box). I extend this to include domestic firms' ability to search the foreign technology space as well.

Also, the extant literature has focused on absorptive capacity as a function of domestic firms' internal technical capability (the dotted arrow). I extend this to include the role of network ties as well.

Levinthal, 1990; Phene \& Almeida, 2008; Todorova \& Durisin, 2007), the spillovers literature has focused largely on their ability to transfer - that is, to assimilate and implement foreign technology (Meyer \& Sinani, 2009; Zahra \& George, 2002).

The second under-examined aspect is the role of network ties in enhancing domestic firms' absorptive capacity. As I have indicated, absorptive capacity is construed in the FDI spillovers literature as a function of the firm's existing technical base. Yet absorptive capacity also depends on the firm's interface with the external environment (Cohen \& Levinthal, 1990). The social networks literature demonstrates that a firm's interface with the external environment, shaped by its social ties with other firms, serves as an excellent source of information in assessing and evaluating new technologies (Burt, 1987; Coleman, Katz, \& Menzel, 1966; Gulati, 2007; Rogers, 2003). Also, network ties are essential to be able to integrate and implement new technologies (McDermott \& Corredoira, 2010; Mors, 2010; Tortoriello \& Krackhardt, 2010). While Findlay (1978) in fact acknowledges the role of networks, and refers specifically to work by scholars such as James Coleman and Everett Rogers, subsequent work on FDI spillovers has rarely engaged with the social networks literature.

In an attempt to bridge these gaps and enrich the theory of FDI spillovers, I prospect the theoretical terrain at the intersection of social networks and FDI spillovers. Drawing from the social network and related literatures, I argue that domestic firms' network ties ease their constraints in searching the foreign technology space, and in the subsequent inward transfer of foreign technology. Network ties are thus an important constituent of domestic firms' absorptive capacity relevant to FDI spillovers. I show this in Figure 2, along with portraying visually how my paper extends extant research.

As a prologue to developing my arguments, I elaborate on the search and transfer stages of FDI spillovers in the following section, and highlight the constraints inherent in both these stages.

Search and Transfer Constraints in FDI Spillovers Fundamentally, FDI spillovers occur when domestic firms adopt foreign technologies. And as I have indicated, the process of adopting a new technology is two-staged, with an initial search phase, and a subsequent transfer phase (Hansen, 1999). In the search stage, domestic firms aim to overcome uncertainties over which foreign technology to adopt (Burt, 1987; Suarez, 2005). This is crucial, as potential adopters usually "have limited information about ... costs and benefit ... and may therefore associate [adoption of new technologies] with a high degree of risk" (Blomström \& Kokko, 1998: 250). The goal in the search phase is thus to gain a general awareness of the various foreign technologies that are available, their basic features, and their relative usefulness (Rowley, Behrens, \& Krackhardt, 2000). Once the search process reveals a useful technology or set of technologies, the domestic firm then needs to orchestrate its actual adoption. This involves migration of the technology from the source firm, and its integration into the domestic firm's existing operations. Scholars refer to this as the transfer phase of the adoption process (Hansen, 1999; Kotabe et al., 2003).

Both search and transfer require cooperation, coordination, and information exchange between foreign and domestic firms, but to varying extents. In the search stage, what are needed are discrete bits of relatively simple information on a range of foreign technologies. The focus is not on depth of understanding, but on accessing basic information on several different alternatives - in other words, 
on "identifying viable alternatives rather than fully understanding how to develop any one innovation" (Rowley et al., 2000: 374). Accordingly, access to diverse sources of knowledge is critical. In the transfer stage, on the other hand, the required information exchange between source and recipient is significantly broader and deeper. The exchange is broader, as it consists of the complex set of related routines that together constitute the technology (Kotabe et al., 2003), as well as specific advice on its implementation. The information exchange, relative to the search stage, is also several orders deeper, as the domestic firm requires a more fine-grained and deeper understanding of the specific technology (Rowley et al., 2000). Given sharp differences across firms in language, meaning, and interpretation (Bechky, 2003; Dougherty, 1992; Polidoro, Ahuja, \& Mitchell, 2011), the level of coordination required between source and recipient also increases significantly. Unlike search, the actual transfer and adoption of technology require extensive coordinated interaction between the source and recipient firms (Dyer \& Hatch, 2006; Galbraith, 1990; Kotabe et al., 2003; Teece, 1977).

A further challenge in the case of FDI spillovers, especially intra-industry spillovers, is that foreign and domestic firms are often in competition with each other. So, in addition to the knowledgetransfer difficulties just described, a further hurdle is the lack of incentives for foreign firms to cooperate in the search and transfer process. This presents severe constraints for the informal, nonmarket exchanges that constitute FDI spillovers. The willingness of foreign firms is crucial in both search and transfer, but more so in the latter, given the greater demands placed on foreign firms' effort in and commitment to repeated interaction and information exchange.

\section{Network Ties and FDI Spillovers: Baseline Proposition}

How do domestic firms resolve search and transfer constraints? Based on the social networks and related literatures (such as that on technology upgrading), I maintain that the role of network ties is critical. Network ties differentiate domestic firms in their access to valuable information that facilitates search, and in opportunities for interaction with foreign firms that lubricates transfer. In simple terms, the likelihood of effective FDI spillovers is contingent on network ties.
Broadly speaking, three arguments underpin the relevance of network ties to technology adoption and spillovers. The first focuses on the information benefit of ties (Burt, 1992), where social network ties serve as the "pipes" through which valuable information flows (Podolny, 2001). Since firms often turn to their social contacts (Borgatti \& Cross, 2003; Burt, 1987) to seek information, such ties are likely to be the crucial means "through which a firm ... learns about new practices and techniques and other opportunities" (McEvily \& Zaheer, 1999: 1137). Thus, network ties in general, and - as I will argue later - certain kinds of ties in particular, provide access to diverse sources of knowledge, which in turn foster the search process.

Second, along with providing general awareness, network ties are also conduits for influence and conformity. A firm's ties with others serve as a channel for reciprocally socializing debates (Burt, 1987), and eventually for both firms developing common beliefs about the usefulness and risks of available technologies (Durkheim, 1984; Greve, 1996; Rogers, 2003). This in turn exerts powerful pressures for conformity (Strang \& Soule, 1998: 272). When faced with the uncertainty over whether or not to adopt foreign technology, managers of domestic firms are likely to engage in discussions about these technologies with foreign firms with whom they have established ties. These ties lead to mutually socializing discussions, shared views about the suitability and value of foreign technologies, and, very likely, the decision to conform and adopt.

The third way in which network ties help technology adoption is by providing the context of rich interactions that is crucial to the technology transfer stage (Dyer \& Hatch, 2006; Hansen, 1999; Kotabe et al., 2003). Sharing technology, as argued above, is a challenging collaborative process that requires fairly intense interaction and communication between the transferor and the recipient (Kotabe et al., 2003). Network ties offer a channel for this close interaction. Ties between firms, especially those that have existed for a while (Kotabe et al., 2003), and which involve frequent interaction (Hansen, 1999) or effective knowledgesharing mechanisms (Dyer \& Hatch, 2006), are particularly effective in supporting the transfer of technology. By definition, FDI spillovers refer only to informal knowledge transfers; nevertheless, it is difficult to conceive how transfer might occur in the absence of disciplined interaction between foreign and domestic firms. Based on these arguments, 


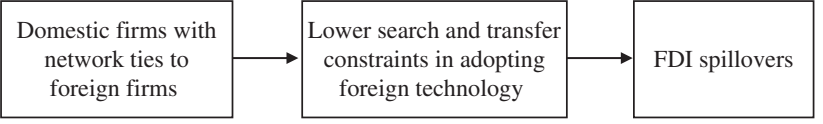

Figure 3 Baseline proposition: network ties, search and transfer constraints, and FDI spillovers.

I suggest the following baseline proposition, which I also represent visually in Figure 3.

(Baseline) Proposition 1: Domestic firms that have network ties to foreign firms, compared with those that do not, are better positioned for search and (inward) transfer of foreign technologies, and thus are more likely to benefit from FDI spillovers.

I now focus on the specific types of ties that help in search and transfer. The key insight here is that not all ties are good vehicles for search; some are more effective for search than for transfer, and vice versa. In particular, I argue in the following section that the search utility of network ties depends on the network structure surrounding the tie (Burt, 1992), and on the affective quality of the tie (Adler \& Kwon, 2002; Kilduff \& Brass, 2010; Ingram \& Roberts, 2000).

\section{Sparse Network Structure, Tie Quality, and Search Constraints}

The technology-upgrading literature has highlighted the importance of the structural-bridging properties of ties (McDermott et al., 2009). Without bridging ties that connect previously disjointed realms of knowledge, networks of a firm may in fact be counterproductive by shielding its awareness of alternatives outside its network (Hoetker, Swaminathan, \& Mitchell, 2007). On the other hand, ties that bridge different knowledge communities offer the focal firm access to diverse sources of knowledge, which is crucial to technology upgrading (McDermott et al., 2009; Mors, 2010; Tortoriello \& Krackhardt, 2010). A parallel argument applies to technology spillovers from foreign firms.

As argued earlier, during the early stages of the adoption process domestic firms seek to gain a broad understanding of what technologies are available, and the relative merits of each. What is useful in this stage is access to a range of available alternative technologies, rather than in-depth information on a few. From this standpoint, the number of ties that domestic firms have with different foreign firms is clearly advantageous, but does not necessarily offer access to diverse knowledge. Network size alone is not indicative of the breadth of information or range of alternative technologies to which domestic firms are exposed.

What actually matters is the bridging properties of the ties - that is, whether or not they offer nonredundant information benefits. In a dense network, where all contacts of a firm are in turn tied to each other, each firm in the network is likely to have the same information. It is unlikely that any one network contact can provide unique information benefits to the focal firm (Burt, 1992: 47). Also, the risk of being cognitively shielded from other alternatives is high (Hansen, 1999; Hoetker et al., 2007). In sparse network structures, on the other hand, the focal firm is tied with other firms that are not in turn tied to each other, and hence ties offer non-redundant benefits. Each tie in this case serves as a bridge to a novel information source (Burt, 1992).

Some scholars insist that bridging ties in sparse networks are weak ties (Granovetter, 1973). I instead adopt Burt's (1992: 28) position that "whether a relationship is strong or weak, it generates information benefits when it is a bridge over a structural hole." Weakness is a correlate of bridging ties, but not the cause of information benefits. This is a tractable stand, as scholars have also argued that "bridges are not always weak ties" (McEvily \& Zaheer, 1999: 1137), preferring to keep the strength of the tie and structure of the network conceptually distinct (Reagans \& McEvily, 2003: 241).

Whether bridging ties are weak or strong, it is clear that the network structure surrounding a tie influences its relevance to a domestic firm's search process. Sparse ties are likely to deliver access to a diverse range of different technologies (Hansen, 1999; Kilduff \& Brass, 2010). They are more likely to yield bridging benefits to the domestic firm, and thus also a fuller (albeit basic) understanding of the foreign technology space.

While I refer mostly to direct, dyadic ties, the same benefits can be attained through indirect, associative ties as well (Safford, 2007; Zuckerman \& Sgourev, 2006). Associative ties are relationships between firms that emerge from co-membership in the same trade associations or industry peer networks. Typically composed of non-competing members, they offer opportunities for members to share information about effective technologies and practices, provide an environment for intense and 
detailed analysis of industry practices, and offer exposure to the diverse practices of members (Safford, 2007; Zuckerman \& Sgourev, 2006). This is in some ways similar to the information sharing and learning that occur in supplier associations of auto manufacturers (Dyer \& Hatch, 2006; Dyer \& Nobeoka, 2000; Helper, MacDuffie, \& Sabel, 2000; Sako, 1996). While associative and direct ties are different, it is also true that direct ties between firms often precede or follow membership in industry peer associations. In fact, associative ties can be indicative of an underlying network tie or, on the other hand, provide opportunities for ties to develop (Borgatti \& Halgin, 2011). Whether direct or associative, the essential characteristic of ties that is relevant to the search process is their bridging ability. And this arises essentially from the underlying sparseness of the network structure.

Proposition 2: Domestic firms with bridging ties to foreign firms (i.e., associative ties or direct ties embedded in a sparse rather than a dense network structure) have better access to diverse information sources, and thus face lower search constraints.

The content and quality of ties matter just as much (Adler \& Kwon, 2002; Gulati, 2007; Gulati, Nohria, \& Zaheer, 2000; Labianca \& Brass, 2006; McDermott \& Corredoira, 2010). The mere existence of a tie with a foreign firm does not automatically imply that a domestic firm will make use of it in searching for information. Instead, firms differentiate between sources on the basis of how much they know and value the expertise of the source (Borgatti \& Cross, 2003). They are likely to approach and trust information from a source they know well and have access to (Krackhardt, 1992).

However, the perception of familiarity and friendship should also be reciprocated by the foreign firm. When the foreign firm is not willing to help, search becomes difficult and costly (Hansen et al., 2005; Zuckerman \& Sgourev, 2006). Thus, a counteracting force to the effect of ties I have proposed above is the competitive cost for foreign firms of sharing information with their domestic competitors. As "knowledge ... given to competitors costs the giver in terms of relative competitive position" (Ingram \& Lifschitz, 2006: 338), foreign firms do have an incentive to prevent information flows to domestic competitors (Javorcik, 2004).

While this is certainly an argument with merit, it should also be pointed out that not all scholars agree. Scholars from other research streams have argued that ties induce information sharing, even among competitors (Appleyard, 1996). In providing social learning as a theoretical basis for strategic groups, Peteraf and Shanley (1997: 169) acknowledge that "organizations engage in pairwise interactions with one another for a variety of reasons and thus have many opportunities to learn from one another at close range and from the results of their interactions." They also suggest that "opportunities for ... social learning among firms in an industry niche ... increase with the density of the network of associations that connects them" (Peteraf \& Shanley, 1997: 175). Networks of association, they explain, are the patterns of interactions that link firms directly and indirectly. The industrial clusters literature (Krugman, 1991; Porter, 1990) is another example: here, scholars argue that among firms in social and geographical proximity, "new ideas circulate easily from one firm to another, promoting processes of incremental and collective innovation" (Giuliani \& Bell, 2005: 48). Some of these knowledge transfers are part of "information trading" (von Hippel, 1987), where managers exchange information with competitors in anticipation of receiving a similar favor in the future.

Given these opposing views on the effect of ties on information sharing between competitors, the key question becomes which of the network ties between foreign and domestic firms yield good outcomes. My position is that ties enriched with affective emotions are better able to overcome the constraints that competitors face in sharing information (Tsai, 2002). "When the competitor is a friend or family member, an altruistic concern for their outcomes may offset ... the competitive cost" (Ingram \& Lifschitz, 2006: 338). The affective nature of the tie helps balance the decision for foreign firms in favor of information sharing with their domestic competitor. Typically, such altruistic emotions are more characteristic of friendship or kinship based ties than of relationships formed purely for instrumental purposes (Ingram \& Roberts, 2000). Thus, when foreign and domestic firms are competitors, the utility of bridging ties depends a lot on the personal relationship between decision makers on both sides.

Proposition 3: Domestic firms' bridging ties to foreign firms (i.e., associative ties or direct ties embedded in a sparse rather than a dense network structure) are more valuable information sources 
SEARCH STAGE

(Exploring various foreign technology alternatives)

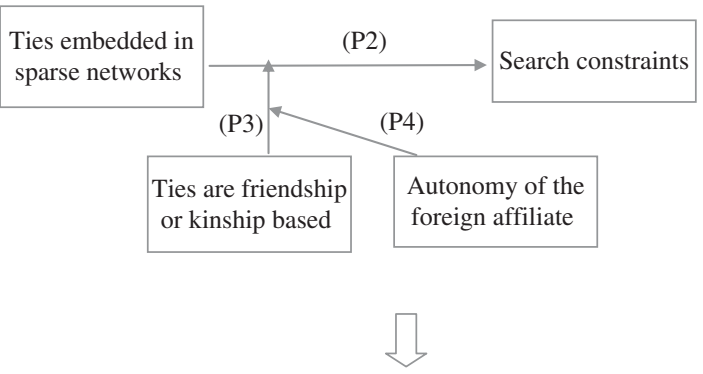

TRANSFER STAGE

(Inward transfer, integration, and implementation of the foreign technology)

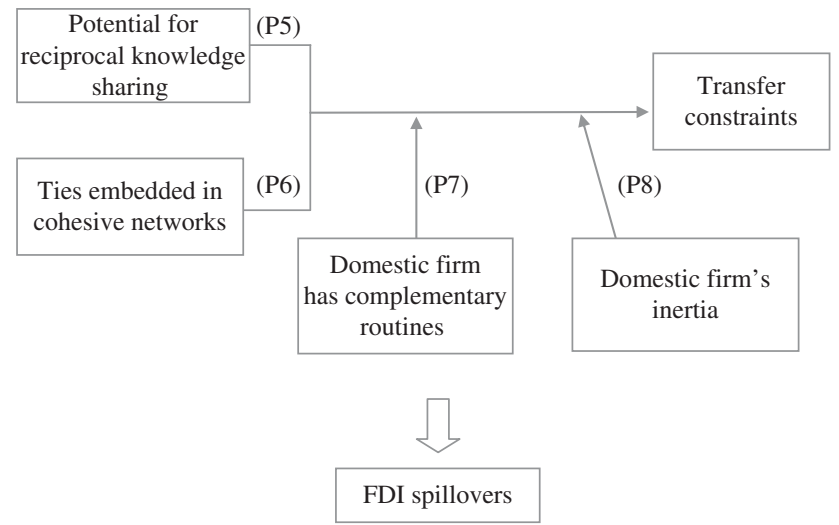

Figure 4 The effect of network ties on search and transfer stages of FDI spillovers.

in the search stage when they are characterized by strong emotional bonds, such as when they are friendship or kinship based.

The usefulness of personal relationships for information exchange, however, also relies on the extent of the autonomy that firms accord to their decision makers. The more measures there are in place to reduce the influence of personal relationships and preferences on corporate decisions, the less likely it is that friendship ties will make any difference. Friendship-based decisions depend on the "role-holder's capacity to develop and employ personal relationships for economic purposes" (Ingram \& Lifschitz, 2006: 340), and flourish only when there are fewer limitations in the form of precedents and rules for managers to comply with. By way of empirical evidence, Ingram and Lifschitz (2006) find there is less trust and knowledgesharing among corporations and more among family-owned businesses. Similarly, Ingram and Roberts (2000) find a significant extent of knowledge-sharing among hotels in Sydney that, while also branches of corporations, were relatively small and autonomous (Ingram \& Lifschitz, 2006). It is worthwhile to note that these arguments are in line with important recent advances in social network theory, which suggest that the usefulness of network ties for a focal firm varies depending on the alter, that is, with whom it is tied (Lin, 2001; McDermott et al., 2009).

Proposition 4: The facilitating effect of friendship or kinship based bridging ties on domestic firms' search increases with the autonomy given to managers of foreign affiliates to which domestic firms are tied.

These relationships are depicted in the upper panel of Figure 4.

\section{Potential for Future Reciprocity, Dense Network Structure, and Transfer Constraints}

Once the search stage yields a promising foreign technology (or set of technologies), the next step involves its inward transfer and implementation. While bridging ties provide access to diverse knowledge essential to technology upgrading, for it to be of any use the recipient must be able to integrate and successfully implement the new technology. And herein lie several difficulties. The innovation literature has highlighted that even across different units of the same organization there is seldom common ground of understanding. Instead, there are sharp interpretative and contextual differences (Bechky, 2003; Carlile, 2004; Dougherty, 1992). When it comes to knowledge transfer and integration across firm boundaries, these differences in language and meaning are sharper, rendering knowledge transfer more challenging (Kogut \& Zander, 1992; Tortoriello \& Krackhardt, 2010). Thus, while sparse ties confer benefits of access to a wide range of diverse knowledge, they do not automatically ensure that firms can integrate and implement them (Mors, 2010; Obstfeld, 2005); "having new ideas is fundamentally different from implementing new ideas" (Tortoriello \& Krackhardt, 2010: 168).

What makes for successful knowledge transfer that cuts across these interpretative barriers is regular interaction between the source and recipient. Prior research has shown that it is only in contexts that provide for disciplined and intense interactions that knowledge transfer is successful (McDermott \& Corredoira, 2010). In the context of 
FDI spillovers, as discussed, this raises additional problems because the source - the foreign firm needs to overlook the competitive implications of transferring knowledge. A key constraint at the transfer stage is thus the motivation of foreign firms to invest time and effort in sustained (informal) interactions.

In the following, I argue that the willingness and motivation of foreign firms increase with their anticipation of future reciprocity, and with the density of the network structure surrounding a tie. More specifically, the willingness to engage in the fine-grained interactions necessary for transfer increases when the foreign firm anticipates future reciprocal benefits, and with the social control that comes with dense underlying network structures (Coleman, 1988; Mors, 2010; Polidoro Jr. et al., 2011; Tortoriello \& Krackhardt, 2010). These relationships are portrayed in the lower half of Figure 4.

\section{Potential for future reciprocity}

Sharing information between competitors becomes easier when there is potential for reciprocal knowledge exchange (Giuliani, 2007; Giuliani \& Bell, 2005; Larson, 1992). It helps at this point to distinguish between information leakage and trading (von Hippel, 1987; Schrader, 1991). While losing information to a competitor is indeed costly, many firms are "more willing to provide information if they can expect to receive valuable information in return" (Schrader, 1991: 168). These firms consciously engage in information trading whereby the initial cost of giving away information is recovered when the recipient returns the favor. So the motivation to share information with competitors rests partly on the potential for future reciprocity. This idea resonates heavily in some of the interviews that von Hippel (1987: 295) conducted with managers of steel minimills. A manager at Bayou Steel stated, "How much is exchanged depends on what the other guy knows - must be reciprocal." At Chaparral Steel the remark was: "If they don't let us in [to their plant] we won't let them in [to ours] - must be reciprocal" (von Hippel, 1987: 295).

While the benefits foreign firms foresee from domestic firms may not be technical in nature, there are areas of knowledge relating to the host market that domestic firms could potentially exchange. These include local market knowledge, network and political contacts, and access to distribution assets. Foreign firms that foresee several rounds of swapping knowledge or other benefits in the future are arguably more inclined to share information in the present. It may not necessarily be the size of benefits that motivates foreign firms but rather the potential for repeated rounds of mutually beneficial information exchange (Larson, 1992: 90).

A related pertinent issue is how foreign firms form perceptions about the reciprocity potential of domestic firms. How do they know ex ante if a particular domestic firm is capable of reciprocating by sharing valuable knowledge? This is less of a problem if there have been prior interactions between the foreign and domestic firms, but in the absence of that, the quality and capability of domestic firms may appear opaque to external constituents. In such situations of imperfect information, the reputation and status of domestic firms assume significance (Kreps \& Wilson, 1982). In keeping with the underlying theme of this paper, I draw attention to the fact that domestic firms' social ties serve as signals of their status and reputation (Podolny, 1993, 2001; Stuart, Hoang, \& Hybels, 1999). Domestic firms' ties to other prominent firms in the industry can act as a signaling device to foreign firms, and shape their perceptions of the quality of those firms (Podolny, 1994; Stuart et al., 1999). Ties with high-status firms also flag the reliability of the focal domestic firms, because it is unlikely that high-status firms will persist in relationships with unreliable firms (Stuart et al., 1999). These kinds of associative endorsements can act as strong signals in favor of domestic firms, and it is likely to be in these firms that foreign firms see the potential for reciprocal information sharing.

Irrespective of how the perception is formed, the key point is that foreign firms are motivated to cooperate in the transfer stage when they perceive the potential for reciprocity. Thus:

Proposition 5: Domestic firms with ties to foreign firms, wherein the foreign firm perceives it to have current or future potential to reciprocate knowledge exchange, face lower constraints in the transfer stage of spillovers.

\section{Dense networks and knowledge transfer}

As mentioned earlier, knowledge transfer and integration across firm boundaries are inherently difficult (Dyer \& Hatch, 2006; McDermott \& 
Corredoira, 2010; Reagans \& McEvily, 2003). In the context of FDI spillovers, even if the foreign firm is motivated to cooperate, it can be deterred by the possibility that the domestic firm will subsequently engage in opportunistic behaviors. What is necessary to stimulate prolonged interactive relationships, then, is additional monitoring and enforcement mechanisms. The dyadic strength inherent in friendship ties is useful to some extent, but when it comes to sharing potentially sensitive information, there need to be additional motivating and monitoring mechanisms. At this juncture, the social monitoring and control conferred by dense network structures and common third-party ties assume significance (Coleman, 1988; Mors, 2010; Polidoro et al., 2011; Reagans \& McEvily, 2003; Tortoriello \& Krackhardt, 2010).

Ties embedded in dense structures - that is, with many common third-party ties - have advantages in terms of minimizing the prospects of opportunistic behavior and ensuring norms of cooperation (Polidoro et al., 2011; Reagans \& McEvily, 2003; Tortoriello \& Krackhardt, 2010). Participants in such network structures face reputation consequences if they act opportunistically or refuse to behave cooperatively; "if they do not cooperate, news of their uncooperative behavior will spread to other network members quickly and limit their ability to interact with them in the future" (Reagans \& McEvily, 2003: 246). The closure offered by common third-party ties also has a stabilizing effect, which in turn establishes cooperative behavior as the norm (Coleman, 1988). Particularly in contexts where competitive persuasions between source and recipients serve as impediments to knowledge-sharing, the cooperation and willingness induced by such cohesive network structures are useful (Reagans \& McEvily, 2003). Furthermore, "increased stability promotes the formation of common language and shared understandings among the parties involved" (Tortoriello \& Krackhardt, 2010: 170), which is crucial to integrating the diverse sources of knowledge to which bridging ties provide access.

So while sparse ties help search, the inward transfer and implementation of foreign technology are facilitated better through ties embedded in dense networks. Thus:

Proposition 6: Domestic firms with ties to foreign firms that are embedded in dense (rather than sparse) networks face lower constraints in the transfer stage of spillovers.

\section{Domestic Firms' Routine Repertoire: Complementary Routines and Inertia}

\section{Complementary routines}

Even with the willingness of foreign firms to cooperate, for knowledge transfer to be successful, domestic firms must possess the capability to integrate foreign technologies into their existing operations (McEvily \& Marcus, 2005). At this integration stage, an understanding of the core technology alone will not suffice; a mastery of complementary routines and capabilities is required (Nelson \& Winter, 1982). These are not necessarily technical in nature. Given that domestic firms seek technology spillovers with the objective of commercializing new products, complementary routines include planning, logistics, marketing, and management skills (Baranson, 1969; Hall \& Johnson, 1970; Mowery \& Rosenberg, 1989). As Teece (1986: 288) writes: "In almost all cases, the successful commercialization of an innovation requires that the know-how in question be utilized in conjunction with other capabilities or assets. Services such as marketing, competitive manufacturing, and after-sales support are almost always needed." The type and extent of complementary capabilities needed depend on the kind of technology domestic firms seek to implement. Depending on the technology, the required complementary capabilities could be generic, specialized, or co-specialized (Teece, 1986: 289). While generic capabilities are general-purpose and apply to most technologies, co-specialized capabilities are those tailored specifically for the technology in question. Specialized skills, on the other hand, lie in the middle, and include some specificity to the technology. Irrespective of the specificity of the routine, the effectiveness of the transfer stage of spillovers depends on the extent to which domestic firms possess the relevant routines and capabilities (Blalock \& Simon, 2009; McEvily \& Marcus, 2005).

Where do these routines and capabilities come from? To some extent they are a product of incremental learning processes within firms (Helfat, 2000; Nelson \& Winter, 1982). Alternatively, they evolve through interactions in past ties between the recipient and source firms (Dyer \& Hatch, 2006; McEvily \& Marcus, 2005; McEvily \& Zaheer, 1999). Close interaction offers opportunities for mutual understanding of each other's operating routines, and thus greater transparency in the associated routines that make a piece of technology work (Kotabe et al., 2003; McEvily \& Marcus, 2005). 
These interactions could very well be formal ones, including formal licensing or joint-venture agreements with the foreign firm. So even though technology spillovers are, by definition, informal, the relevant complementary routines could have evolved through past formal ties with the source firm (Hamel, Doz, \& Prahalad, 1989). The key point, thus, is that complementary routines and capabilities are crucial to successfully integrating foreign technology, and that these can evolve through past interactions with the foreign firm. Put differently, domestic firms with past ties with foreign firms are more likely to possess complementary routines and capabilities relevant to the technology they seek to adopt from the latter in the spillover process. This makes adoption easier.

While this is a valuable insight in its own right, I am interested in its implications for the effect of network ties that I have proposed above. The key role served by dense ties and ties wherein the foreign firm sees potential for future reciprocity, as argued above, is securing foreign firms' cooperation during the transfer stage of spillovers. Also, they facilitate the interaction crucial to effective transfer of complex technology and associated routines. Both these functions are less important when the domestic firm already has the relevant complementary routines. In other words, the domestic firm's possession of complementary routines substitutes, to some extent, the utility of ties during the transfer stage. Incentives are less of a hurdle, because the transfer process is less demanding on the foreign firm in terms of time and effort, and transfer difficulties are also relatively lower, because the domestic firm already has the relevant routines. To be clear, ties still serve important facilitating functions, but these are likely to be more advantageous for domestic firms lacking relevant complementary routines. In this sense, the importance of ties in lowering transfer constraints attenuates with the complementary routine repertoire of the domestic firm.

Proposition 7: The effect of network ties on lowering constraints in the transfer stage is weaker for domestic firms that possess capabilities and routines complementary to the foreign technology being integrated.

\section{Inertia}

While routines complementary to the foreign technology being adopted make transfer easier (and the role of ties to some extent superfluous), the existing non-complementary routines of a domestic firm can have the opposite effect, and constitute difficulties arising from inertia. Inertial pressures naturally serve as a hurdle for domestic firms to implement and adapt to new technologies.

Firms are inert for several reasons. The same reasons that make replicating a firm's routines difficult (Nelson \& Winter, 1982) also render replacing existing ones tedious. Given the tacit nature of routines, it is often not even clear which routines need changing. And since a firm's current routines are composed of the individual skills of its members, it is not guaranteed that those individual skills will extend to the new routines. Inertia could also arise from past learning processes. Firms learn and develop competencies in certain areas and technologies, which simultaneously push them into "traps of distinctive competence" (Levinthal \& March, 1993). In other words, their distinctive competencies inhibit their abilities to adapt or extend into other competencies. Inertia could also emanate from pressures to maintain political equilibrium within the firm, from the potential loss of legitimacy following fundamental change (Hannan \& Freeman, 1989), and from the cascade of subsequent change it provokes (Hannan, Pólos, \& Carroll, 2003a, b).

Recent theory suggests there are variations in the strength of inertia (Hannan \& Freeman, 1984, 1989; Hannan, Pólos, \& Carroll, 2004; Zajac \& Shortell, 1989). That is, some kinds of changes are more difficult to make than others, and some kinds of firms are more prone to inertia than others (Greve, 1996; Hannan \& Freeman, 1984). Two characteristics thought to influence the strength of inertia are firm age and firm size (Hannan \& Freeman, 1984, 1989; Haveman, 1993). Newer organizations have fewer or less rigid routines and administrative heritage, and have had less time for members to invest in organization-specific skills, or to form coalitions powerful enough to resist change within the organization. The pressure to continue without change is also thus considerably less. Older organizations, on the other hand, tend to be more inert, as procedures, roles, and structures become well established over time (Barron, West, \& Hannan, 1994). The likelihood of change thus decreases with age (Amburgey, Kelly, \& Barnett, 1993; Delacroix \& Swaminathan, 1991; Miller \& Chen, 1994). Hannan and Freeman (1984) also argue that larger organizations are less likely to change, owing to the associated bureaucratic structures. Small organizations have fewer bureaucratic overheads, and thus 
can be more flexible than large ones (Haveman, 1993). However, this argument is not entirely supported, as some scholars suggest that larger organizations have better access to resources to facilitate change (Aldrich \& Auster, 1986), and some empirical studies find support for the same (Huber, Sutcliffe, Miller, \& Glick, 1993).

Varying levels of inertia have two implications for FDI spillovers. First, adopting foreign technologies often involves a range of structural changes within the domestic firm. In fact, the theory of structural inertia pertains to changes in the core features of organizations (not peripheral ones), and one of the four features that constitute the core is the basic technology used to transform inputs into outputs (Hannan \& Freeman, 1984; Hannan et al., 2003b). By this argument, the adoption of foreign technologies is more strenuous and unlikely when the domestic firm is subject to constraints of inertia. But just as in the case of complementary routines, our interest lies more in how inertia influences the role of network ties in transfer constraints. The key to my argument here is the idea that a firm's network ties can influence its propensity to adapt (Kraatz, 1998). When faced with the option or need to change, "what decision makers considering such changes may most need is ... richer, more detailed information regarding the implications, desirability, and feasibility of ... alternatives" (Kraatz, 1998: 624). These are the very benefits afforded by the dense ties described earlier. Ties thus play an enabling role when domestic firms are faced with inertial pressures, "facilitating organizations' attempts to adapt their core features" (Kraatz, 1998: 623). The implication of this train of logic is that while ties with the characteristics I have described above foster the spillover process by reducing domestic firms' transfer constraints, this utility matters significantly more for domestic firms with inertial constraints. In other words, among domestic firms, those with inertial constraints to change benefit more from the persuasive advantages conferred by ties (Kraatz, 1998).

Proposition 8: The effect of network ties on lowering constraints in the transfer stage is stronger for domestic firms that face inertial constraints on adopting foreign technologies.

\section{DISCUSSION}

This paper explores issues at the intersection of the FDI spillovers and social network literatures. The motivation to do so comes from trying to address two specific gaps in the FDI spillovers literature. The first is the relatively narrow framing of absorptive capacity in the literature, which includes only the transfer stage of spillovers while overlooking the search process that usually precedes transfer. The second is the predication of absorptive capacity on the internal technical capabilities of domestic firms, with fairly little reference to the role of their network ties. In trying to bridge these gaps, I develop a theoretical framework of how domestic firms' structure of social relationships influences their search and transfer constraints, and consequently their likelihood of benefiting from technology spillovers.

I maintain that network ties with foreign firms help reduce search and transfer constraints, but the underlying network structures conducive to search and transfer are different. The search process benefits from sparse structures, while transfer requires cohesive network structures. Also, while affect-based ties might motivate foreign firms sufficiently to share information at the search stage, significantly more motivation in the form of anticipated reciprocal benefits and social monitoring conferred by common third-party ties is necessary in the transfer stage. Any effect of ties, however, also depends on the routine repertoire of domestic firms - that is, on their possession of complementary skills and low inertial constraints to change.

\section{Scholarly and Practical Implications}

These arguments have important implications for the FDI spillovers literature. First, they extend current conceptions of absorptive capacity by bringing to the forefront search constraints faced by domestic firms. As argued earlier, so far there has been relatively limited attention given to this issue. At the extreme, one could also argue that there is an implicit assumption in the extant literature that domestic firms have uniform access to information about foreign technologies. This is problematic, because the assumption does not reconcile with views held in organization theory by economists (e.g., Arrow, 1974; Hennart, 1982) or sociologists (e.g., Burt, 1987; Greve, 1996; Rogers, 2003) regarding uncertainty in the technology-adoption process. The fresh argument that this paper brings to the spillovers literature is that domestic firms are differentiated in their access to information, and in their ability to resolve search problems, and I present this ability as a crucial component of 
domestic firms' absorptive capacity (Todorova \& Durisin, 2007).

Second, drawing from the social networks literature, I suggest network ties as the discriminating factor in domestic firms' ability to resolve search and transfer constraints. Network ties between domestic and foreign firms serve as conduits of information pertaining to foreign technologies, and domestic firms with such ties are better at resolving search and transfer constraints. This line of argument brings unprecedented attention to the role of social structure in FDI spillovers. Spencer (2008) has discussed how local linkages between foreign and domestic firms aid spillovers. This paper builds on her work, but also extends it by highlighting the mechanisms underlying the utility of ties, the role of different types of ties, and the circumstances under which they are useful.

Integrating social structure into the spillover process leads to a third important conceptual advancement: it draws attention to the social mechanisms underpinning FDI spillovers. It reconciles the theory of spillovers with arguments in economic sociology that economic action is influenced by an actor's social connections with other actors. Mainstream economics and economic sociology differ in their assumptions about the "actor" and "economic action." While the actor in economics is the individual, without consideration for his social connections, the actor in economic sociology is conceptualized as "actor-in-interaction" or "actor-in-society" (Smelser \& Swedberg, 2005). Sociologists take into account influences from other related persons and groups in the analysis of economic action (Granovetter, 1985). This notion is very succinctly laid out in the following quote: "For a person who grows up in a high-crime neighbourhood, the choice between making a career stealing and getting a job has often less to do with the comparative utility of these two alternatives than with the structure of peer groups and gangs in the neighbourhood" (Smelser \& Swedberg, 2005: 5).

My focus on both the search and transfer stages of FDI spillovers also yields a process-based conceptualization of spillovers. This is yet another extension of the literature, which hitherto has focused largely on when and where spillovers are likely to occur. For example, Lipsey and Sjoholm (2005: 40) state: "The question shifts from how inward FDI affects every host country and industry to which types of industries and host countries are affected ... [the challenge lies in] identifying the characteristics of firm, industries and countries that promote the transfer of technology." Understanding the process of spillovers is equally important. I make an initial attempt at this by elaborating on the search and transfer stages. The focus on both stages also brings attention to the notion that there might be variations in the quality of spillovers to domestic firms. Firms that are embedded in dense networks are better off in integrating and implementing technologies, but would be constrained in their search. If they are shielded from a wide range of alternatives in their search, this could in turn mean they end up with technologies that may not be optimal, irrespective of the fact that implementation is less problematic. Firms embedded in sparse networks face the opposite problem. While they have access to a broader range of technology options, and this awareness may possibly lead to some productivity improvements, they may lose out on the benefits of the technology, owing to difficulties in its implementation. In other words, the quality of spillovers depends on having the right network ties at the right stage.

This paper also provides new kinds of domestic firm heterogeneity that need to be accounted for in future research. Scholars have been aware that domestic firms should not be considered "passive recipients of spillovers," and that their "own strategies and resource endowments are crucial for benefitting from interaction with foreign investors" (Meyer, 2004: 267). Recent research has also stressed the need to model this heterogeneity in domestic firms (Blalock \& Gertler, 2009; Blalock \& Simon, 2009; Meyer, 2004; Spencer, 2008: 356-357). My work is consistent with this view, and I suggest further sources of domestic firm heterogeneity: their network ties with foreign firms, the extent to which they possess complementary skills, and their inertia towards change.

Finally, the theory developed here has implications for policymakers. In general, an awareness of the conditions wherein spillovers are more likely enables governments to better prepare and support domestic firms in extracting these spillovers (Spencer, 2008). From a policy point of view, if social ties of domestic firms play crucial roles in effecting spillovers, governments need to actively nurture these ties (McDermott et al., 2009). Arguably, much governmental effort currently is spent attracting foreign investors to the country (Moran, 2001). The salience of social ties suggests that parallel efforts need to be spent encouraging the appropriate ties that will serve as channels for 
spillovers. The theory here also implies the need to target specific groups of domestic firms that have higher potential to absorb spillovers. The arguments laid out here suggest that firms that possess complementary capabilities and lower resistance to change are potentially more likely to benefit from technology spillovers. To get the most benefit for their efforts, governments need to specifically target this group in their efforts to raise the productivity of the domestic industry.

\section{Boundaries of the model}

When discussing the implications of the model, it is probably worthwhile also to clarify its boundaries. First, throughout the discussion I have assumed that foreign MNEs are technologically superior to domestic firms, and that spillovers occur from MNEs to domestic firms. For the most part, this limits the applicability of the framework to emerging and transition economies, where this assumption is more likely to be true. Scholars have documented spillovers from domestic to foreign MNEs (Singh, 2007) and, even in an emerging market, among foreign MNEs in a host country (Feinberg \& Majumdar, 2001; Tan \& Meyer, 2011). I do not explicitly consider either of these scenarios in my model.

Second, the model is relevant only in cases where search and transfer constraints are likely to be high. Search and transfer constraints are irrelevant when there is little or no uncertainty surrounding the features of the technology, and if it is fairly simple to incorporate into the existing routines of the domestic firm. For standardized, less complex technologies, network ties are unlikely to be relevant mechanisms in their diffusion.

My arguments are also to a great extent valid in the context of vertical spillovers. The first issue that raises constraints in the transfer stage is competitive considerations between foreign and domestic firms, and the second is the inherent difficulty in transferring complex knowledge. Since foreign and domestic firms in vertically related industries are typically not competitors, one could assume that foreign firms might be more willing to share information. In fact, foreign firms may even benefit from doing so (Javorcik, 2004). So the competitive constraints are relatively lower. However, despite the willingness of the foreign firms, prior literature has shown that technology upgrading of suppliers, even in the framework of formal contracts, is still difficult (McDermott \& Corredoira, 2010). So, while the motivation-related arguments in my model might be more relevant to horizontal spillovers, the transfer-related constraints that arise from the difficulties of integrating new knowledge also very much apply to vertical spillovers.

\section{Future conceptual extensions}

I have basically characterized foreign firms as a bridge between domestic firms and the pool of knowledge about foreign technologies. Thus, the effectiveness of network ties surely depends on the ability of foreign firms to serve as good bridges. In pushing this research forward, it is worthwhile examining factors that differentiate foreign firms in their bridging ability. These could include the strategies and technical capabilities of individual foreign firms, the extent to which the foreign firm has access to essential knowledge, and its centrality in the global and domestic networks of firms (McDermott et al., 2009).

Another potential extension is to consider other firms or non-firm organizations that act as bridges for domestic firms. ${ }^{4}$ One possibility is that domestic firms that have already adopted foreign technologies serve in a bridging role. In other words, alongside a domestic firm's ties with foreign firms (which have been the focus of this paper), its ties with other domestic firms that have already adopted foreign technologies could be important in reducing search and transfer constraints. In a similar way, a domestic firm's ties to government-supported institutions that have access to information about foreign technologies could also be effective (McDermott et al., 2009; McEvily \& Zaheer, 1999; Pietrobelli \& Rabellotti, 2011). Technology spillovers in these circumstances occur even if a domestic firm's ties are not to foreign firms, but instead to other firm or non-firm entities that have access to relevant information.

\section{Empirical Strategy}

While my main preoccupation in this paper has been to reframe conceptual understanding of the search and transfer abilities of domestic firms and how they relate to spillovers, some discussion on empirical measurement and testing is also worthwhile. While I do not claim to offer an exhaustive empirical strategy, I discuss a few points here.

A good place to start is with conventional methods of testing FDI spillovers in the literature (e.g., Blalock \& Simon, 2009; Zhang et al., 2010). These conventional econometric specifications can be extended to accommodate parts of the 
conceptual arguments I put forth in this paper. A direct extension, for example, is the inclusion of domestic firms' network ties as additional explanatory variables, such that productivity is regressed on various measures of network ties and structure. Staying in the realm of using archival, large-scale datasets, network ties could be proxied by strategic alliances (Polidoro et al., 2011) or indirect associative ties (Zuckerman \& Sgourev, 2006) between domestic and foreign firms. The ties I theorize about are informal in nature (except in Proposition 5), so this empirical specification will overlap perfectly with my conceptual arguments only if one could argue that loosely formalized strategic alliances and associative ties - compared with, say, formal buyer-supplier ties and joint ventures - are informal in nature.

I will elaborate a little more on collecting better data on informal ties but, assuming I have data on ties, operationalizing the key variables in my model is fairly straightforward. The literature on social networks offers several alternative ways of measuring the density (or sparseness) of the underlying network structure. The essential differentiator between sparse and dense networks is whether or not a focal firm's contacts are connected between themselves. In sparse networks that are conducive to search, they are not, but in the dense networks necessary for transfer, they are. A basic operationalization of this structural characteristic is the number of common third-party ties (Polidoro et al., 2011) between a domestic firm and its foreign contact. Another commonly used density measure is the ratio of actual to possible number of ties between firms (Ingram \& Roberts, 2000), although such a measure is a network-level one, and lacks any dyadic characteristic (McDermott et al., 2009). So as a first stab at empirical testing, one could augment conventional specifications with additional measures of network ties.

I maintain that these specifications test only parts of my conceptual arguments. One relatively simple reason for this is that, besides the density of networks, my model proposes variables covering the affective content of ties and the extent to which foreign firms perceive reciprocal benefits. Data for these variables are best collected using surveys or interviews, as I describe below. However, more fundamentally, conventional specifications are partial tests, because while my model encapsulates both the search and transfer stages of the process of spillovers, examining the effect of network ties on domestic firm productivity tests only the second stage. It does not capture the search process effectively.

As a remedy, one possibility is to test search and transfer stages separately in two different specifications. A model that could inform such an approach is Hansen et al. (2005), where the authors study two different dependent variables - search costs and transfer costs, proxied by the time spent on search and transfer - and how these costs are influenced by network ties. Alternatively, one could still simultaneously include variables related to the search and transfer stage in a conventional model with productivity as a dependent variable. A result where the explanatory power of the latter exceeds that of the former would be consistent with my conceptual model.

Nevertheless, to really be able to capture network variables, as much of the social network literature has done, one needs to use interview or survey data. Typically, social network researchers use sociometric or ego-centric techniques to generate a list of informal interaction ties of a focal firm (McDermott \& Corredoira, 2010). In the former, respondents are presented with a fixed list of other participants and asked to describe their relationship with each (e.g., Tsai, 2002). For the ego-centric technique, researchers use name-generating questions that elicit from respondents a roster of contacts. Then they describes their relationship with each (Ingram \& Roberts, 2000; Reagans \& McEvily, 2003). Often self-reports of respondents are also confirmed by reports from their contacts as well, to avoid informant bias and to obtain a more reliable measure (Krackhardt, 1990; Tortoriello \& Krackhardt, 2010; Tsai, 2002). There are immense advantages in mimicking the approach of the social networks scholars. It allows the obvious benefits that data can be obtained on the affective content of the tie, and on the perception of foreign firms on the potential for reciprocal knowledge exchange - two important variables in my model. More importantly, perhaps, it allows for finer levels of analysis of spillovers at the dyad level. While the effect of ties can still be related to firm-level outcomes (McDermott \& Corredoira, 2010), search and transfer constraints can also be measured (as a dependent variable) at the level of each dyadic tie of domestic firms with foreign firms, similar to the approach in Reagans and McEvily (2003). ${ }^{5}$

A slightly more difficult issue that calls for creative research designs is testing the process aspects of the model. The empirical strategies I 
have described above do not necessarily test the two-stage process of spillovers. To accurately test process models, one would need longitudinal designs. The archival and survey methods described above can, with quite some effort, be extended into longitudinal designs, but it may also be worthwhile exploring alternative methodologies, such as computational modeling and agent-based simulations. Simulation research has not received a lot of attention in the management literature (Harrison, Lin, Carroll, \& Carley, 2007), and to my knowledge has never been used in the FDI spillovers literature. Yet simulation methods such as agent-based models could be quite useful in examining the temporal process of spillovers (Gilbert, 2007). Also, simulations have been used in studies of firms' explorative behavior (Corredoira, 2009), and in the search and evaluation of alternative technologies for adoption (Bullnheimer, Dawid, \& Zeller, 1998). Simulation methods are also routinely used to study how micro-level interactions between actors (such as social network ties) influence the diffusion of technology (Bae \& Coo, 2008; Centola \& Macy, 2007; Strang \& Macy, 2001), which essentially is the very process underlying FDI spillovers as well. A detailed specification of a simulation study is beyond the scope of this paper, but it would certainly be worthwhile for future research to explore this possibility.

In summary, this paper provides a conceptual framework of how social structure shapes the (absorptive) capacity of domestic firms to benefit from FDI spillovers. Together with the alternative empirical designs I have proposed, this sets the stage for further conceptual and empirical research into the social mechanisms underlying the spillover process.

\section{ACKNOWLEDGEMENTS}

I thank Anand Swaminathan and three anonymous reviewers, Arjen Slangen, Chinmay Pattnaik, Rekha Krishnan, Roger Smeets, and Vikas Kumar for their helpful comments on this paper.

\section{NOTES}

${ }^{1}$ In this paper, I use the terms "technology spillovers," "productivity spillovers," and "FDI spillovers" interchangeably, and to mean the same thing: spillovers of technology know-how from foreign to domestic firms in the host country.
${ }^{2}$ I thank an anonymous reviewer for pointing out that the autonomy of the MNE subsidiary is also an important precondition for spillovers. A tightly controlled subsidiary may not have the discretion to share knowledge with domestic firms. But, at the same time, autonomy without incentives is not helpful. An autonomous subsidiary will not share knowledge unless there are sufficient incentives or motivating factors. I build on this point in the lead up to Proposition 4.

${ }^{3}$ An early precursor to this idea is Hirschman's (1958) theory of unbalanced growth. Hirschman challenged the concept of "balanced economic growth" prevalent at the time, and argued that because of the linkages between sectors, the planned development of only some of them - that is, unbalanced growth - would automatically stimulate latent entrepreneurial activity in related sectors. A rise in demand and price in one sector would therefore stimulate latent entrepreneurship in sectors that supplied complementary products. Linkages could also take the form of direct relationships between firms in vertically related industries, with foreign firms providing technical and managerial support to bring domestic suppliers up to speed (Lall, 1980). While these are in effect formal transfers to domestic suppliers, Markusen and Venebles (1999) and Rodriguez-Clare (1996) extend the argument to include indirect effects. That is, as foreign firms establish backward linkages that build and strengthen supply industries, this in turn benefits other domestic firms in downstream sectors that source intermediates from these industries.

${ }^{4} \mathrm{I}$ thank an anonymous reviewer for raising this point.

${ }^{5}$ Data requirements are obviously more demanding. First, I would need to move away from the large-scale multi-industry data approach in conventional spillovers studies to single-industry or geographically contained studies, so that data collection is more tractable. Second, missing data become a more important concern (Borgatti, Carley, \& Krackhardt, 2006), because "each missing case removes the $N-1$ possible relationships with other network actors" (Ingram \& Roberts, 2000: 399). Common method bias can also be a problem if the dependent variable is collected from the same survey. Yet I do not see these as significant hindrances, but rather as issues of which scholars need to be aware and careful (McDermott \& Corredoira, 2010). Some scholars have handled common method bias by collecting data on dependent and independent variables from sequential surveys of the same respondents (Tsai, 2002). 


\section{REFERENCES}

Adler, P. S., \& Kwon, S. -W. 2002. Social capital: Prospects for a new concept. Academy of Management Review, 27(1): 17-40.

Aldrich, H. E., \& Auster, E. R. 1986. Even dwarfs started small: Liabilities of age and their strategic implications. Research in Organization Behavior, 8: 165-198.

Amburgey, T. L., Kelly, D., \& Barnett, W. P. 1993. Resetting the clock: The dynamics of organizational change and failure. Administrative Science Quarterly, 38(1): 51-73.

Appleyard, M. M. 1996. How does knowledge flow? Interfirm patterns in the semiconductor industry. Strategic Management Journal, 17(winter special issue): 137-154.

Arrow, K. 1974. Essays in the theory of risk bearing. Amsterdam: North-Holland Publishing.

Ayyagari, M., \& Kosova, R. 2010. Does FDI facilitate domestic entry? Evidence from the Czech Republic. Review of International Economics, 18(1): 14-29.

Bae, J., \& Coo, J. 2008. Information loss, knowledge transfer cost and the value of social relations. Strategic Organization, 6(3): 227-258.

Baranson, J. 1969. Industrial technologies for developing economies. New York: Praeger.

Barron, J. N., West, E., \& Hannan, M. T. 1994. A time to grow and a time to die: Growth and mortality of credit unions in New York City, 1914-1990. American Journal of Sociology, 100(2): 381-421.

Bechky, B. A. 2003. Sharing meaning across occupational communities: The transformation of understanding on a production floor. Organization Science, 14(3): 312-320.

Blalock, G., \& Gertler, P. J. 2009. How firm capabilities affect who benefits from foreign technology. Journal of Development Economics 90(2): 192-199.

Blalock, G., \& Simon, D. H. 2009. Do all firms benefit equally from downstream FDI? The moderating effect of local suppliers' capabilities on productivity gains. Journal of International Business Studies, 40(7): 1095-1112.

Blomström, M., \& Kokko, A. 1998. Multinational corporations and spillovers. Journal of Economic Surveys, 12(3): 247-277.

Borgatti, S. P., \& Cross, R. 2003. A relational view of information seeking and learning in social networks. Management Science, 49(4): 432-445.

Borgatti, S. P., \& Halgin, D. S. 2011. On network theory. Organization Science, 22(5): 1168-1181.

Borgatti, S. P., Carley, K. M., \& Krackhardt, D. 2006. On the robustness of centrality measures under conditions of imperfect data. Social Networks, 28(2): 124-136.

Bullnheimer, B., Dawid, H., \& Zeller, R. 1998. Learning from own and foreign experience: Technological adaptation by imitating firms. Computational \& Mathematical Organization Theory, 4(3): 267-282.

Burt, R. S. 1987. Social contagion and innovation: Cohesion versus structural equivalence. The American Journal of Sociology, 92(6): 1287-1335.

Burt, R. S. 1992. Structural holes: The social structure of competition. Cambridge, MA: Harvard University Press.

Carlile, P. R. 2004. Transferring, translating, and transforming: An integrative framework for managing knowledge across boundaries. Organization Science, 15(5): 555-568.

Centola, D., \& Macy, M. 2007. Complex contagions and the weakness of long ties. American Journal of Sociology, 113(3): 702-734.

Chang, S. -J., \& Xu, D. 2008. Spillovers and competition among foreign and local firms in China. Strategic Management Journal, 29(5): 495-518.

Cohen, W. M., \& Levinthal, D. A. 1990. Absorptive capacity: A new perspective on learning and innovation. Administrative Science Quarterly, 35(1): 128-152.

Coleman, J. S. 1988. Social capital in the creation of human capital. American Journal of Sociology, 94(Supplement): S95-S120.

Coleman, J. S., Katz, E., \& Menzel, H. 1966. Medical innovation. New York: Bobbs-Merrill.
Corredoira, R. A. 2009. Embedded exploration: The role of inter-firm networks in channelling organizational search, Unpublished PhD Dissertation, Wharton School, University of Pennsylvania.

Delacroix, J., \& Swaminathan, A. 1991. Cosmetic, speculative and adaptive change in the wine industry: A longitudinal study. Administrative Science Quarterly, 36(4): 631-661.

Dougherty, D. 1992. Interpretive barriers to successful product innovation in large firms. Organization Science, 3(2): 179-202.

Durkheim, E. 1984. The division of labour in society. New York: Free Press.

Dyer, J. H., \& Hatch, N. W. 2006. Relation-specific capabilities and barriers to knowledge transfers: Creating advantage through network relationships. Strategic Management Journal, 27(8): 701-719.

Dyer, J. H., \& Nobeoka, K. 2000. Creating and managing a highperformance knowledge-sharing network: The Toyota case. Strategic Management Journal, 21(3): 345-367.

Eden, L. 2009. Letter from the editor-in-chief: FDI spillovers and linkages. Journal of International Business Studies, 40(7): 1065-1069.

Feinberg, S. E., \& Majumdar, S. K. 2001. Technology spillovers from foreign direct investment in the Indian pharmaceutical industry. Journal of International Business Studies, 32(3): 421-437.

Findlay, R. 1978. Relative backwardness, direct foreign investment, and the transfer of technology: A simple dynamic model. Quarterly Journal of Economics, 92(1): 1-16.

Galbraith, C. 1990. Transferring core manufacturing technologies in high technology firms. California Management Review, 32(4): 56-70.

Gilbert, N. 2007. Agent-based models. Los Angeles: Sage Publications.

Girma, S. 2005. Absorptive capacity and productivity spillovers from FDI: A threshold regression analysis. Oxford Bulletin of Economics and Statistics, 67(3): 281-306.

Giuliani, E. 2007. The selective nature of knowledge networks in clusters: Evidence from the wine industry. Journal of Economic Geography, 7(2): 139-168.

Giuliani, E., \& Bell, M. 2005. The micro-determinants of mesolevel learning and innovation: Evidence from a Chilean wine cluster. Research Policy, 34(1): 47-68.

Giuliani, E., Pietrobelli, C., \& Rabellotti, R. 2005. Upgrading in global value chains: Lessons from Latin American clusters. World Development, 33(4): 549-573.

Görg, H., \& Strobl, E. 2001. Multinational companies and productivity spillovers: A meta-analysis. The Economic Journal, 111(475): 723-739.

Granovetter, M. S. 1973. The strength of weak ties. American Journal of Sociology, 78(6): 1360-1380.

Granovetter, M. S. 1985. Economic action and social structure: The problem of embeddedness. American Journal of Sociology, 91(3): 481-510.

Greve, H. R. 1996. Patterns of competition: The diffusion of a market position in radio broadcasting. Administrative Science Quarterly, 41(1): 29-60.

Gu, Q., \& Lu, J. W. 2011. Effects of inward investment on outward investment: The venture capitalist industry worldwide 1985-2007. Journal of International Business Studies, 42(2): 263-284.

Gulati, R. 2007. Managing network resources: Alliances, affiliations, and other relational assets. New York: Oxford.

Gulati, R., Nohria, N., \& Zaheer, A. 2000. Strategic networks. Strategic Management Journal, 21(3): 203-215.

Hall, G., \& Johnson, R. 1970. Transfer of US aerospace technology to Japan. In R. Vernon (Ed.), The technology factor in international trade: 303-364. New York: Columbia University Press.

Hamel, G., Doz, Y., \& Prahalad, C. K. 1989. Collaborate with your competitors and win. Harvard Business Review, 67(1): 133-139. 
Hannan, M. T., \& Freeman, J. 1984. Structural inertia and organizational change. American Sociological Review, 49(April): 149-164.

Hannan, M. T., \& Freeman, J. 1989. Organizational ecology. Cambridge, MA: Harvard University Press.

Hannan, M. T., Pólos, L., \& Carroll, G. 2003a. The fog of change: Opacity and asperity in organizations. Administrative Science Quarterly, 48(3): 399-432.

Hannan, M. T., Pólos, L., \& Carroll, G. 2003b. Cascading organizational change. Organization Science, 14(5): 463-482.

Hannan, M. T., Pólos, L., \& Carroll, G. 2004. The evolution of inertia. Industrial and Corporate Change, 13(1): 213-242.

Hansen, M. T. 1999. The search-transfer problem: The role of weak ties in sharing knowledge across organization subunits. Administrative Science Quarterly, 44(1): 82-111.

Hansen, M. T., Mors, M. L., \& Lovas, B. 2005. Knowledge sharing in organizations: Multiple networks, multiple phases. Academy of Management Journal, 48(5): 776-793.

Harrison, J. R., Lin, Z., Carroll, G. R., \& Carley, K. M. 2007. Simulation modeling in organizational and management research. Academy of Management Review, 32(4): 1229-1245.

Haskel, J. E., Pereira, S. C., \& Slaughter, M. J. 2002. Does inward foreign direct investment boost the productivity of domestic firms?, NBER Working Paper 8724, National Bureau of Economic Research, Washington DC.

Haveman, H. 1993. Organizational size and change: Diversification in the savings and loan industry after deregulation. Administrative Science Quarterly, 38(1): 20-50.

Helfat, C. E. 2000. Guest editor's introduction to the special issue: The evolution of firm capabilities. Strategic Management Journal, 21(10-11): 955-959.

Helper, S., MacDuffie, J. P., \& Sabel, C. 2000. Pragmatic collaborations: Advancing knowledge while controlling opportunism. Industrial and Corporate Change, 9(3): 443-488.

Hennart, J. -F. 1982. A theory of multinational enterprise. Ann Arbor: University of Michigan Press.

Hirschman, A. O. 1958. The strategy of economic development. New Haven, CT: Yale University Press.

Hoetker, G., Swaminathan, A., \& Mitchell, W. 2007. Modularity and the impact of buyer-supplier relationships on the survival of suppliers. Management Science, 53(2): 178-191.

Huber, G. P., Sutcliffe, K. M., Miller, C. C., \& Glick, W. H. 1993. Understanding and predicting organizational change. In G. P. Huber \& W. H. Glick (Eds), Organizational change and redesign: 215-263. New York: Oxford.

Hymer, S. 1976. The international operations of national firms: $A$ study of direct foreign investment. Boston: MIT Press.

Ingram, P., \& Lifschitz, A. 2006. Kinship in the shadow of the corporation: The interbuilder network in Clyde river shipbuilding, 1711-1990. American Sociological Review, 71(2): 334-352.

Ingram, P., \& Roberts, P. W. 2000. Friendships among competitors in the Sydney hotel industry. American Journal of Sociology, 106(2): 387-423.

Javorcik, B. S. 2004. Does foreign direct investment increase the productivity of domestic firms? In search of spillovers through backward linkages. American Economic Review, 94(3): 605627.

Kilduff, M., \& Brass, D. J. 2010. Organizational social network research: Core ideas and key debates. Academy of Management Annals, 4(1): 317-357.

Kogut, B., \& Zander, U. 1992. Knowledge of the firm, combinative capabilities, and the replication of technology. Organization Science, 3(3): 383-397.

Kotabe, M., Martin, X., \& Domoto, H. 2003. Gaining from vertical partnerships: Knowledge transfer, relationship duration, and supplier performance improvement in the US and Japanese automotive industries. Strategic Management Journal, 24(4): 293-316.

Kraatz, M. S. 1998. Learning by association? Interorganizational networks and adaptation to environmental change. Academy of Management Journal, 41(6): 621-643.
Krackhardt, D. 1990. Assessing the political landscape: Structure, cognition, and power in organizations. Administrative Science Quarterly, 35(2): 342-369.

Krackhardt, D. 1992. The strength of strong ties: The importance of philos in organizations. In N. Nohria \& R. G. Eccles (Eds), Networks and organizations: Structure, form, and action: 216-239. Cambridge, MA: Harvard Business School Press.

Kreps, D. M., \& Wilson, R. 1982. Reputation and imperfect information. Journal of Economic Theory, 27(2): 253-279.

Krugman, P. 1991. Increasing returns and economic geography. Journal of Political Economy, 99(3): 483-499.

Labianca, G., \& Brass, D. J. 2006. Exploring the social ledger: Negative relationships and negative asymmetry in social networks in organizations. Academy of Management Review, 31(3): 596-614.

Lall, S. 1980. Vertical inter-firm linkages in LDCs: An empirical study. Oxford Bulletin of Economics and Statistics, 42(3): 203-226.

Larson, A. 1992. Network dyads in entrepreneurial settings: A study of the governance of exchange relationships. Administrative Science Quarterly, 37(1): 76-104.

Levinthal, D. A., \& March, J. G. 1993. The myopia of learning. Strategic Management Journal, 14(S2): 95-112.

Lin, N. 2001. Social capital. New York: Cambridge University Press. Lipsey, R. E., \& Sjoholm, F. 2005. The impact of inward FDI on host countries: Why such different answers?. In T. H. Moran, E. M. Graham, \& M. Blomström (Eds), Does foreign direct investment promote development? 23-43. Washington, DC: Peterson Institute for International Economics.

Liu, X., Siler, P., Wang, C., \& Wei, Y. 2000. Productivity spillovers from foreign direct investment: Evidence from UK industry level panel data. Journal of International Business Studies, 31(3): 407-423.

Liu, X., Wang, C., \& Wei, Y. 2009. Do local manufacturing firms benefit from transactional linkages with multinational enterprises in China? Journal of International Business Studies, 40(7): 1113-1130.

Liu, X., Lu, J., Filatotchev, I., Buck, T., \& Wright, M. 2010. Returnee entrepreneurs, knowledge spillovers, and innovation in high-tech firms in emerging economies. Journal of International Business Studies, 41(7): 1183-1197.

MacDougall, G. D. A. 1960. The benefits and costs of private investment from abroad: A theoretical approach. Economic Record, 36(73): 13-35.

Markusen, J. R., \& Venebles, A. J. 1999. Foreign direct investment as a catalyst for industrial development. European Economic Review, 43(2): 335-356.

McDermott, G. A., \& Corredoira, R. A. 2010. Network and composition, collaborative ties, and upgrading in emergingmarket firms: Lessons from the Argentine autoparts sector. lournal of International Business Studies, 41(2): 308-329.

McDermott, G. A., Corredoira, R. A., \& Kruse, G. 2009. Publicprivate institutions as catalysts of upgrading in emerging market societies. Academy of Management Journal, 52(6): 1270-1296.

McEvily, B., \& Marcus, A. 2005. Embedded ties and the acquisition of competitive capabilities. Strategic Management Journal, 26(11): 1033-1055.

McEvily, B., \& Zaheer, A. 1999. Bridging ties: A source of firm heterogeneity in competitive capabilities. Strategic Management Journal, 20(12): 1133-1156.

Meyer, K. 2004. Perspectives on multinational enterprises in emerging economies. Journal of International Business Studies, 35(4): 259-276.

Meyer, K. E., \& Sinani, E. 2009. When and where does foreign direct investment generate positive spillovers? A meta-analysis. Journal of International Business Studies, 40(7): 1075-1094.

Miller, D., \& Chen, M. J. 1994. Sources and consequences of competitive inertia: A study of the US airline industry. Administrative Science Quarterly, 39(1): 1-23.

Moran, T. H. 2001. Parental supervision: The new paradigm for foreign direct investment. Washington, DC: Institute for International Economics. 
Mors, M. L. 2010. Innovation in a global consulting firm: When the problem is too much diversity. Strategic Management Journal, 31(8): 841-872.

Mowery, D., \& Rosenberg, N. 1989. Technology and the pursuit of economic growth. Cambridge: Cambridge University Press.

Nelson, R. R., \& Winter, S. G. 1982. An evolutionary theory of economic change. Cambridge, MA: Harvard University Press.

Obstfeld, D. 2005. Social networks, the Tertius iungens orientation, and involvement in innovation. Administrative Science Quarterly, 50(1): 100-130.

Peteraf, M., \& Shanley, M. 1997. Getting to know you: A theory of strategic group identity. Strategic Management Journal, 18(S1): 165-186.

Phene, A., \& Almeida, P. 2008. Innovation in multinational subsidiaries: The role of knowledge assimilation and subsidiary capabilities. Journal of International Business Studies, 39(5): 901919.

Pietrobelli, C., \& Rabellotti, R. 2011. Global value chains meet innovation systems: Are there learning opportunities for developing countries? World Development, 39(7): 1261-1269.

Podolny, J. M. 1993. A status-based model of market competition. American Journal of Sociology, 98(4): 829-872.

Podolny, J. M. 1994. Market uncertainty and the social character of economic exchange. Administrative Science Quarterly, 39(3): $458-483$.

Podolny, J. M. 2001. Networks as the pipes and prisms of the market. American Journal of Sociology, 107(1): 33-60.

Polidoro Jr., F., Ahuja, G., \& Mitchell, W. 2011. When the social structure overshadows competitive incentives: The effects of network embeddedness on joint venture dissolution. Academy of Management Journal, 54(1): 203-223.

Porter, M. 1990. The competitive advantage of nations. London: Macmillan.

Reagans, R., \& McEvily, B. 2003. Network structure and knowledge transfer: The effects of cohesion and range. Administrative Science Quarterly, 48(2): 240-267.

Rodriguez-Clare, A. 1996. Multinationals, linkages, and economic development. American Economic Review, 86(4): 852-873.

Rogers, E. M. 2003. Diffusion of innovations. New York: Free Press.

Rowley, T., Behrens, D., \& Krackhardt, D. 2000. Redundant governance structures: An analysis of structural and relational embeddedness in the steel and semiconductor industries. Strategic Management Journal, 21(3): 369-386.

Safford, S. 2007. Why the garden club couldn't save Youngstown: Civic infrastructure and mobilization in economic crises, MIT Local Innovation Systems Working Paper 04-003, MIT, Cambridge, MA.

Sako, M. 1996. Suppliers' associations in the Japanese automobile industry: Collective action for technology diffusion. Cambridge Journal of Economics, 20(6): 651-671.

Saxenian, A. 1994. Regional advantage: Culture and competition in Silicon Valley and Route 128. Cambridge, MA: Harvard University Press.

Schrader, S. 1991. Informal technology transfer between firms: Cooperation through information trading. Research Policy, 20(2): 153-170.

Sinani, E., \& Meyer, K. E. 2004. Spillovers of technology transfer from FDI: The case of Estonia. Journal of Comparative Economics, 32(3): 445-466.

Singh, J. 2007. Asymmetry of knowledge spillovers between MNCs and host country firms. Journal of International Business Studies, 38(5): 764-786.

Smelser, N. J., \& Swedberg, R. 2005. Introducing economic sociology. In N. J. Smelser \& R. Swedberg (Eds), The handbook of economic sociology, (2nd edn): 3-25. Princeton, NJ: Russell Sage Foundation/Princeton University Press.

Spencer, J. W. 2008. The impact of multinational enterprise strategy on indigenous enterprises: Horizontal spillovers and crowding out in developing countries. Academy of Management Review, 33(2): 341-361.

Strang, D., \& Macy, M. W. 2001. In search of excellence: Fads, success stories, and adaptive emulation. American Journal of Sociology, 107(1): 147-182.

Strang, D., \& Soule, S. A. 1998. Diffusion in organizations and social movements: From hybrid corn to poison pills. Annual Review of Sociology, 24: 265-290.

Stuart, T. E., Hoang, H., \& Hybels, R. C. 1999. Interorganizational endorsements and the performance of entrepreneurial ventures. Administrative Science Quarterly, 44(2): 315-349.

Suarez, F. F. 2005. Network effects revisited: The role of strong ties in technology selection. Academy of Management Journal, 48(4): 710-720.

Tan, D., \& Meyer, K. 2011. Country of origin and industry FDI agglomeration of foreign investors in an emerging economy. Journal of International Business Studies, 42(4): 504-520.

Teece, D. J. 1977. Technology transfer by multinational firms: The resource cost of transferring technological know-how. Economic Journal, 87(346): 242-261.

Teece, D. J. 1986. Profiting from technological innovation: Implications for integration, collaboration, licensing and public policy. Research Policy, 15(6): 285-305.

Todorova, G., \& Durisin, B. 2007. Absorptive capacity: Valuing a reconceptualization. Academy of Management Review, 32(3): 774-786.

Tortoriello, M., \& Krackhardt, D. 2010. Activating crossboundary knowledge: The role of Simmelian ties in the generation of innovations. Academy of Management Journal, 53(1): 167-181.

Tsai, W. 2002. Social structure of "coopetition" within a multiunit organization: Coordination, competition, and intraorganizational knowledge sharing. Organization Science, 13(2): 179-190.

Uzzi, B. 1997. Social structure and competition in interfirm networks: The paradox of embeddedness. Administrative Science Quarterly, 42(1): 35-67.

von Hippel, E. 1987. Cooperation between rivals: Informal know-how trading. Research Policy, 16(6): 291-302.

Zahra, S. A., \& George, G. 2002. Absorptive capacity: A review, reconceptualization, and extension. Academy of Management Review, 27(2): 185-203.

Zajac, E. J., \& Shortell, S. M. 1989. Changing generic strategies: Likelihood, direction, and performance implications. Strategic Management Journal, 10(5): 413-430.

Zhang, Y., Li, H., Li, Y., \& Zhou, L. -A. 2010. FDI spillovers in an emerging market: The role of foreign firms' country origin diversity and domestic firms' absorptive capacity. Strategic Management Journal, 31(9): 969-989.

Zuckerman, E. W., \& Sgourev, S. V. 2006. Peer capitalism: Parallel relationships in the US economy. American Journal of Sociology, 111(5): 1327-1366.

\section{ABOUT THE AUTHOR}

Alex Eapen is a Lecturer (Assistant Professor) at the University of Sydney Business School. He earned his $\mathrm{PhD}$ in business from Tilburg University, and was a finalist for the 2007 Gunnar Hedlund doctoral dissertation prize. His research interests include market entry modes, especially strategic alliances, and the subsequent impact of MNE entry on domestic firms, for example, through knowledge spillovers. 